\author{
Elizabeth A. Povinelli
}

Columbia University, New York, NY, USA

\title{
Pragmáticas íntimas: linguagem, subjetividade e gênero
}

\begin{abstract}
Resumo: Este artigo discute entendimentos metapragmáticos e psicanalíticos de linguagem, gênero e desejo. Discute o desafio que cada abordagem disciplinar sobre linguagem, gênero e desejo coloca uma para a outra. Argumenta que uma teoria robusta de linguagem e gênero precisa que a subjetividade seja vista como uma ordem de fenômeno distinta das ordens semântica e pragmática do fenômeno linguístico. O artigo sugere duas propostas modestas como uma maneira de começar a entender a inter-relação entre linguagem e subjetividade. Começa com um breve panorama das abordagens linguístico-antropológicas para gênero e sexualidade. Então descreve a pragmática íntima do sujeito falante articulando trabalhos recentes sobre metapragmática e gênero com uma abordagem de inspiração psicanalítica sobre subjetividade e desejo.
\end{abstract}

Palavras-chave: linguagem; gênero; metapragmática; psicanálise; subjetividade.

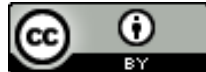

Esta obra está sob licença Creative Commons. uma pessoa se torna

[uma mulher]

para tornar-se

novamente. [mas]

[desfeita]

\section{Loco moção}

1 Artigo traduzido por Joana Plaza Pinto, da Universidade Federal de Goiás. Foi publicado pela primeira vez em francês na revista Anthropologie et Sociétés, v. 23, n. 3,1999 , p. 121-147, e traduzido de texto inédito em inglês por Michelle Mauffette. Uma versão condensada em inglês foi publicada na coletânea Language, Culture, and Society, organizada
O calor do deserto era opressivo.' Em volta da boca, narinas e olhos, a presença irritante de moscas. É o ano de 1896. Baldwin Spencer e Frank Gillen estavam acampados logo ao oeste de Alice Springs, na Austrália. Gillen tinha convidado homens e mulheres aranda e seus vizinhos aborígenes para se reunirem não muito longe de lá para realizarem uma representação do repertório de seus rituais em troca de comida, tabaco, chá e proteção contra criadores de gado e polícia. Baldwin Spencer é um zoólogo, 
por Christine Jourdan e Kevin Tuite (Cambridge University Press, 2006, p. 190-206). O artigo em francês é a fonte da tradução. A versão em inglês do artigo fo consultada e usada para acréscimos de referências bibliográficas. A própria autora foi consultada, no caso de um dilema específico (ver nota 9). Agradecemos imensamente a Elizabeth Povinelli e à revista Anthropologie et Sociétés por autorizarem gentilmente a publicação desta tradução, com a única condição de que fossem divulgados os créditos e de que tivessem acesso à versão publicada. [Nota da tradutora].

${ }^{2}$ George STOCKING, 1995, p. 94 98; John MULVANEY et al., 1997.

3 Baldwin SPENCER and Frank GILLEN, 1899, p. 97.
Frank Gillen um telegrafista. Os dois homens aspiram tornarem-se líderes intelectuais da antropologia australiana nascente. Por isso, todos os dias, eles tiram fotos, rabiscam notas, sentam perto dos velhos Aranda - de nomes atualmente desconhecidos -, que, por sua vez sentados, lutam para responder à enxurrada de perguntas que Spencer e Gillen despejam neles sobre as cerimônias realizadas. Spencer e Gillen estavam felizes em suar, inalar moscas, esticar uma perna com câimbras. Eles conheciam a natureza inédita do espetáculo que testemunhavam. Diante deles se desenrolava sem dúvida o corpus inteiro da cultura masculina do deserto central. A partir dessas performances, Spencer e Gillen iriam publicar em 1899 uma obra etnográfica que se tornaria a pedra angular da geração seguinte de antropólogos aspirantes. ${ }^{2}$

Em alguns momentos, Spencer e Gillen devem ter desviado os olhos de sua escrita e voltado o olhar para os abdomens distendidos das crianças e para as costas devastadas pelo chumbo grosso de homens e mulheres aranda. Quando Spencer colocou no chão seus gizes de cera para ajudar seus informantes aranda a traçar suas genealogias, ele deve ter ouvido histórias completas ou fragmentadas de epidemias, de envenenamentos e dos massacres que explicavam por que tantas árvores genealógicas aranda apresentavam ramos sem continuidade. Mas The native tribes of Central Australia não se interessa por esses corpos escandalosamente maltratados. A obra se preocupa muito mais com aquilo que seus autores e a jovem nação australiana de colonos consideravam como o escândalo moral das práticas rituais aborígenes. O texto faz eco à ansiedade pública a respeito da verdade secreta das corroborees, cuja menção era feita por todo tipo de textos midiáticos: jornais, memoriais populares da vida de colonizadores, etnografias amadoras. As corroborees, festas sagradas dos homens, incluíam sexo grupal. Sim, Spencer e Gillen escrevem, é verdade.

\begin{abstract}
Licença considerável é dada em certas ocasiões, quando um número grande de homens e mulheres se junta para performar certas corroborees [...]. Todo dia duas ou três mulheres são designadas a comparecer no terreno da corroboree e, com exceção dos homens que são seus parentes diretos como pai, irmão ou filhos, elas são, durante o período, propriedade comum a todos os homens presentes no terreno da corroboree. ${ }^{3}$
\end{abstract}

Spencer, Gillen e a maior parte de seus sucessores achavam evidente que aquilo que eles viram (ou aquilo que eles ouviram falar) era "sexo" entre "homens" e "mulheres"; 
${ }^{4}$ SPENCER and GILLEN, 1899, p. 98.

5 O número 3 , do volume 23 , da Anthropologie et Sociétés, fol inteiramente dedicado à Etnolinguística. [Nota da tradutora]

\begin{abstract}
- Para tentativas críticas de ler a psicanálise à luz da semiótica, ver Deborah CAMERON and Dan KULICK, 2003; Julia KRISTEVA 1980; Teresa DE LAURETIS, 1984; Vincent CRAPANZANO, 1993, 1998.
\end{abstract}

7 Jacques LACAN, 1977a, p. 78 Ver também Elizabeth GROSZ, 1990; Joan COPJEC, 1994; and Juliet MITCHELL, 1985. que, quando eles próprios ou os Aranda apontavam um ato sexual, todos apontavam um mesmo campo de ação; que este ato comportava uma sintaxe social, aquela dos homens explorando sexualmente as mulheres; e, enfim, que se poderia extrair dessa atividade sexual a hierarquia indígena dos gêneros. $E$, ainda que Spencer e Gillen fizessem parte do paradigma relativista que começava a alvorecer nas ciências sociais, eles definiam sem pestanejar o que era para eles uma relação sexual normal: "A primeira é a normal, quando a mulher é propriedade privada do homem, e nenhum outro sem seu consentimento pode ter acesso a ela" ${ }^{4}$

Pode parecer singular começar uma revista de estudos contemporâneos da linguagem, do gênero e da sexualidade ${ }^{5}$ pela história de um escândalo sexual. Para muitos, seria ainda mais estranho que esta apresentação começasse pela interpretação de Freud dos textos de Spencer e Gillen ou pela interpretação freudiana do simbolismo falocêntrico dos rituais aranda segundo Geza Roheim ou ainda pelo texto "A significação do falo" de Lacan. Numerosos/as especialistas contemporâneos/as da linguagem se insurgem contra o entrelaçamento inextricável da teoria social, da filosofia continental e dos modelos obsoletos emprestados da linguística pós-saussuriana, entrelaçamento sobre o qual se apoia a psicanálise, sobretudo lacaniana, e que ela retoma por sua conta; contra a exploração de uma economia psíquica universal a partir das estruturas linguísticas particulares aos europeus; e contra a fusão dos aspectos textuais e locucionais da denotação e da predicação. ${ }^{\circ}$

Esse ranger de dentes se faz ouvir mesmo se, e talvez porque, numerosos/as pesquisadores/as que se interessam por gênero e por sexualidade na antropologia da linguagem compartilham com a psicanálise lacaniana certa genealogia intelectual comum e parecem compartilhar certos interesses intelectuais. Em particular, eles/as procuram compreender como os sujeitos caracterizados por seu gênero e seu sexo (grosso modo, homens e mulheres) tornam-se, como tais, sujeitos de seu gênero e seu sexo através da linguagem, ${ }^{7}$ como esses sujeitos vêm a ter desejos e como seus desejos são organizados de maneiras ao mesmo tempo normativa e não normativa. Além disso, a noção de inconsciente é essencial nas explicações que a psicanálise e a antropologia da linguagem produziram sobre o modo como a linguagem elabora quadros normativos e criativos do social. A antropologia da linguagem norte-americana abordou a questão do inconsciente do ponto de vista do signo: ela pergunta como as formas semióticas permitem e restringem a compreensão reflexiva que o sujeito tem das formas e funções linguísticas. A capacidade de os/as 
${ }^{8}$ Ver Sigmund FREUD, 1989; Geza ROHEIM, 1973, 1974 locutores/as tornarem-se conscientes da sistemática gramatical é limitada pelo fato de que o instrumento formal que eles utilizam para representar e descrever seu sistema linguístico, enquanto ferramenta referencial, é também extraído do próprio sistema. Whorf notou há muito tempo que, em razão da imbricação de todas as metalinguagens na língua objeto de estudo, os/as locutores/as apresentam viés sistemáticos na apreensão da estrutura linguística. Whorf considerava que certa má apreensão e as emoções que ela suscita constituíam o componente ideológico que os/as antropólogos/as da linguagem descrevem geralmente como "o inconsciente".

Contudo, Lacan e a escola freudiana não tiveram a pretensão de se interessar pela linguagem por ela mesma. Lacan era, sobretudo, tomado pela compreensão da "paixão do significante", visão estranhamente católica da transubstanciação psíquica a que se submetem os humanos, tornando-se sujeitos graças à linguagem. ${ }^{8}$ Ainda que Lacan tenha concebido que a diferença sexual constitui a diferença significante da linguagem (o Outro), ele em definitivo não se interessava pelas particularidades linguísticas para saber como a linguagem assinala as diferenças sexuais, nem para compreender como essas particularidades produziam sujeitos que têm um gênero. Por outro lado, é justamente pela linguagem que se interessam os/as antropólogos/as que trabalham com as perspectivas teóricas da sociolinguística, da antropologia da linguagem e da pragmática. Entretanto, sociolinguistas e antropólogos/ as da linguagem evitam, por sua parte, abordar a relação formal entre pré-linguagem e pós-linguagem; eles/as escamoteiam, assim, o nascimento do sujeito dotado de gênero e estudam, sobretudo, como a cultura, a consciência e o desejo são produzidos socialmente no decorrer do processo de interação comunicativa. "Identifica-se" a subjetividade nas formas e funções linguísticas, sem lograr alguma teoria da mediação que opera a subjetividade. Não evoquei a obra de Lacan e a psicanálise com o único propósito de condenar sua herança. Admitamos que Lacan leu muito mal (ou - mais amavelmente - que ele reimplantou com criatividade) os conceitos-chave do paradigma estrutural de Jakobson; admitamos também que ele concedeu com magnanimidade o papel de estrutura psíquica universal às particularidades da língua francesa. Isso não impede que o interesse que Lacan assumiu pela teorização da relação formal entre linguagem e desejo, e entre sujeito pré-linguístico e pós-linguístico, coloque um desafio tão desconcertante aos trabalhos da antropologia da linguagem sobre gênero, sexualidade e desejo quanto esses últimos à psicanálise lacaniana. $O$ desafio que a 
$9 \mathrm{O}$ artigo em francês utiliza a expressão "grammaire intime", enquanto $o$ artigo em inglês utiliza a expressão "intimate pragmatics" no decorrer da argumentação. Seguindo os argumentos do texto as referências bibliográficas utilizadas (especialmente Silverstein 1993) e em consulta à autora, optamos por "pragmática íntima". [Nota da tradutora] psicanálise lacaniana coloca para a antropologia da linguagem, a sociolinguística e a pragmática consiste em descobrir como estudar linguagem, desejo e gênero sem reduzi-los uns aos outros. O desafio que a antropologia da linguagem coloca para a teoria psicanalítica é da mesma forma formidável: ele consiste em reformular uma teoria da diferença sexual que não seja baseada exclusivamente nem sobre a estrutura das línguas europeias nem sobre os estudos estruturalistas pós-saussurianos da linguagem. Esse desafio situa, sobretudo, a reflexão sobre gênero e sexualidade no interior das condições semânticas e pragmáticas, metassemânticas e metapragmáticas, que fazem com que sejamos e nos tornemos sujeitos humanos.

Esse ensaio não fará mais do que arranhar a pele ainda em incubação da besta que eu proponho pôr no mundo. Coloco aqui duas modestas proposições para servir de ponto de partida: de início, que nós tentemos teorizar aquilo que descrevo provisoriamente como uma pragmática íntima, ${ }^{9}$ articulando os trabalhos recentes consagrados à metapragmática e ao gênero a um enunciado de inspiração psicanalítica sobre subjetividade e desejo. Começo por uma breve revisão das abordagens antropológicas da semântica, da pragmática e da metapragmática. Tratarei em seguida das relações entre gênero - compreendido de um ponto de vista metapragmático -, subjetividade e desejo. Retomarei ao longo do artigo o encontro histórico dos colonos australianos com os Aranda, que servirá de fio condutor para a abordagem teórica que proponho.

\section{Contexto e conteúdo (a tal "sexualidade" e outros elos pragmáticos)}

Ao longo dos últimos quinze anos, os estudos da linguagem, do gênero e da sexualidade que a antropologia suscitou produziram, por um lado, um dispositivo metodológico e teórico sólido e rigoroso destinado a compreender as relações entre os aspectos semânticos, pragmáticos e metapragmáticos da linguagem e, por outro lado, a produção, a manutenção e a reprodução social dos aspectos normativos da sexualidade e do gênero. Esses estudos têm feito um exame cada vez mais detalhado dos sistemas gramaticais e pragmáticos relativos a "gênero", "atos sexuais", "sexualidade" e "afeto", compreendidos respectivamente como: as diferenças sexuais codificadas na linguagem que apreendem esses comportamentos, valores, posturas e status indexicalmente associados a seres sexuados; as atividades corporais ligadas ao erotismo codificadas na linguagem; as diferentes identidades, subjetividades, interiorizações de papéis e os status associados aos atos sexuais tais como eles 


\begin{abstract}
${ }^{10}$ Para revisões sobre as abordagens contemporâneas da linguagem e do gênero em CAMERON 1995; HALL and BUCHOLTZ, 1995; HALL, BUCHOLTZ and Birch MOONWOMAN, 1992; Janet HOLMES, 1995; Keith HARVEY and Celia SHALOM, 1997; Mary BUCHOLTZ and Kira HALL, 1995; Sally MCCONNELL-GINET, 1988 ; Sara MILLS, 1995; Susan PHILIPS, Susan STEELE and Christine TANZ, 1987; Victoria BERGVALL, Janet BING and Alice FREED, 1996. Para linguagem e emoções, ver Catherine LUTZ, 1990; Danie ROSENBERG, 1990; Judith IRVINE, 1990; Lila ABU-LUGHOD and Catherine LUTZ, 1990; and Niko BESNIER, 1993.

"Sobre a "linguística crítica", ver CAMERON, 1995; HARVEY and SHALOM, 1997.
\end{abstract}

12 John LYONS, 1977.

${ }^{13}$ Michael SILVERSTEIN, 1993, p.
40-45.
14 Stephen LEVINSON, 1983;
SILVERSTEIN, 1993; Elinor OCHS, 1992, 1996.

${ }^{15}$ OCHS, 1996, p. 411.

16 SILVERSTEIN, 1993, p. 42, maiúsculas no texto. são codificados na linguagem; outras emoções e desejos codificados na linguagem. ${ }^{10}$ Os especialistas da linguagem e do gênero também começaram a compreender como os aspectos gramaticais e pragmáticos da linguagem embutem ou recobrem as economias psíquicas e corporais de sistemas de gênero e de sistemas sexuais e afetivos particulares; como eles delimitam e constrangem o espaço social (o privado, o público, o íntimo, o ritual, o secular, o tabu); e como eles contribuem ativamente para os sistemas materiais e simbólicos de valores, de dominação e de exploração. Qualquer que seja a natureza do "gênero" e da "sexualidade" e quaisquer que sejam os projetos que a "linguística crítica" coloca a esse respeito, esses estudos têm demonstrado a utilidade de ancorar a análise de gênero e sexualidade nos discursos e nas funções semânticas, pragmáticas e metapragmáticas. " Esse quadro de análise nos permite articular as mais delicadas estruturas gramaticais às mais radicais contestações sociais do poder.

Pode revelar-se útil que eu passe rapidamente em revista aquilo que entendo pelos termos semântica, pragmática e metapragmática. Para mim, a semântica remete ao domínio semiótico do sentido, da significação de uma palavra ou da expressão que emana da organização formal e da sistemática gramatical. ${ }^{12}$ Mas, concordando com Silverstein, eu concebo que a semântica não extrai nada além do uso linguístico, da forma de colocar o texto denotativo, seja ele pensado, falado ou escrito. Mesmo assim, em princípio, um universo semântico pode ser extrapolado deste uso - do estudo de eventos linguísticos reais no curso dos quais um texto denotativo é produzido em contexto. ${ }^{13}$

A pragmática estuda o uso da língua, compreendendo o domínio semiótico da indexicalidade da significação. ${ }^{14}$ Com uma definição de índice linguístico inspirada em Peirce, Elinor Ochs descreveu a interface social e linguística na qual se insere a indexicalidade da significação como intermediária. Ochs definiu o índice linguístico como uma estrutura gramatical ou vocal,

Que é usada variavelmente de uma situação para outra e torna-se convencionalmente associada com dimensões particulares situacionais tais que, quando esta estrutura é usada, a forma evoca essas dimensões. ${ }^{15}$

Essas "invocações formais" dependem alternadamente da capacidade do signo indexical de indicar "da sempre movente ocorrência aqui-e-agora de algum sinal (token) para seu PRESSUPOSTO 'CONTEXTO' e/ou para suas IMPLICADAS 'CONSEQUÊNCIAS'". ${ }^{16}$ A pressuposição do contexto e aquilo que decorre dela é a propriedade da indexicalidade que entra em jogo para dar, se assim se pode dizer, um tipo de 
17 Ver SILVERSTEIN, 1993, and William HANKS, 1993.

18 SILVERSTEIN, 1993.
19 Ver também John A. LUCY, 1993 , and LYONS, 1977, sobre a "reflexividade da linguagem". Ver Mikhail BAKHTIN, 1986, sobre "gêneros do discurso".

${ }^{20}$ Esses exemplos foram escolhidos não somente para mostrar a diversidade dos domínios culturais e os "níveis" da prática semiolinguística, mas também as diferentes idades e estados nos quais a encontramos. A mãe samoana (ou o pai) que fala a suas crianças utiliza constantemente sinais semióticos não linguísticos, ao mesmo tempo em que utiliza sinais linguísticos (ela faz mexer o corpo da criança aponta com o dedo os objetos a sua volta etc.). Sobre a socialização da linguagem, ver $\mathrm{OCHS}$ 1988: Bambi B. SCHIEFFELIN and OCHS, 1986. Sobre as técnicas do corpo, ver Pierre BOURDIEU, 1977. Sobre os hijra e os travestis, ver Kira HALL e Veronica O'DONOVAN, 1996; and KULICK, 1998. Sobre linguagem e gênero nas obras de "crescimento pessoal" ver John GRAY, 1992. Encontra-se um comentário crítico em Lauren BERLANT, 1988; Senta TROEMELPLOETZ, 1991; Alice FREED and Alice GREENWOOD, 1996 Candance VOGLER, 1998. A respeito da política linguística da França, ver Craig R. WHITNEY, 1998. Sobre o trabalho, a linguagem e o gênero, ver Alice ECHOLS, 1983 bússola, uma orientação de continuidade no espaço-tempo, religando as situações, as frases, os textos e as interlocuções face a face. Os/as locutores/as são, em grande parte, inconscientes da coerência que confere a indexicalidade, ainda que eles/as dependam dela regularmente em frases como: "Admitamos que isto que eu acabo de dizer agora mesmo sobre as serpentes exprime os sentimentos que eu mantenho por elas" e "Ela é uma mulher, você só tem que olhar seus sapatos". ${ }^{17}$

Ao lado dessas estruturas semânticas e funções pragmáticas, Silverstein ${ }^{18}$ distingue os discursos e funções metapragmáticas de uma maneira que nos será útil aqui.

O discurso metapragmático remete aos discursos das pessoas (o que inclui o discurso acadêmico) sobre o uso da língua: trata-se nomeadamente de enunciados, localmente ou historicamente circunscritos, que têm tratado das regras específicas da etiqueta linguística; eles compreendem os discursos que especificam como se adquirem as diferentes etiquetas linguísticas, que julgam se tal aquisição é sustentável ou não e quais pessoas devem se submeter a ela, assim como os discursos que ditam os contextos de seu uso apropriado. Se a função pragmática remete aos aspectos da linguagem que codificam o contexto e a esse aspecto da natureza do uso linguístico que pressupõe o contexto e o que dele resulta, o discurso metapragmático inclui todas as referências implícitas e explícitas a tais codificações, usos e contextos, próprios ou impróprios. ${ }^{19}$ Os samoanos, que ensinam suas crianças em idade pré-linguística e linguística como elas devem se dirigir aos diferentes membros de sua família; o velho frequentador de uma comunidade hijra ou de travestis, que explica ao recém-chegado como ele deve falar "dela" mesma; o primeiro ministro francês, que pede que os títulos honoríficos das mulheres ministras sejam feminizados; os textos difundidos para grande público e os anúncios televisivos que incitam americanos, homens e mulheres, a mudar sua forma de se dirigir um ao outro; o artigo no The Sidney Morning Herald, elogiando o canto dos chefes samoanos que restabeleceram a harmonia social num bairro do centro da cidade utilizando uma arte oratória tradicional: todas essas situações são exemplos de discursos metapragmáticos explícitos ou implícitos. ${ }^{20}$

A função metapragmática ordena o curso da função pragmática da linguagem para produzir textos coerentes e interpretáveis e eventos interlocutórios de qualquer tipo, de tal maneira que eles constituam um evento de comunicação com êxito ou falha. Por exemplo, a função metapragmática compreende os meios pelos quais locutores/as, de maneira inconsciente na maior parte do tempo, incorporam aos seus atos de interlocução diversas classes ou diversos registros 
${ }^{21}$ Ver Benjamin LEE, 1997, p. 277 320; Jacques DERRIDA, 1982 ; Michael SILVESTEIN and Greg URBAN, 1996

${ }^{22}$ Em inglês no texto-fonte. [Nota da tradutora] de gênero de maneira a lhes conferir a coesão de textos interpretáveis (isto é, coerentes). A função metapragmática é o que dá às locutoras e locutores os meios para construir a partir de atos pragmáticos de fenômenos textuais de uma ordem acima (gêneros, enquadres, conversações). Enquanto na sua função pragmática a palavra "ela" encadeia e pressupõe um contexto, na sua função metapragmática "ela" indica um ato de interlocução, aqui, agora, e ao fazer isso a harmoniza (a articula) a um contexto externo e ao progresso de um texto interno. A função metapragmática é, portanto, decisiva no que diz respeito à maneira pela qual fenômenos textuais e interlocutórios (o que inclui os indivíduos, seu gênero, sua cultura) tornam-se coerentes, duráveis e aparentemente destacáveis de seus contextos locais. ${ }^{21}$ Como mostra o Diagrama $1^{22}$, a função metapragmática confere também a impressão de ordem temporal estável ao centro da volatilidade e da natureza transitória da elaboração do sentido. Ainda que todo signo denotativo possa, - e de fato deva, ressignificar a inteira sequência precedente de significação, a função metapragmática assegura que, na maior parte das trocas comunicacionais e, de fato, na própria "cultura", com as identidades que ela define, como, por exemplo, gênero - se faça a experiência de uma totalidade estável e suficientemente coerente.

\section{Diagrama 1}

[a]

$\mathrm{X}$ : She went out.

Y: She did? I thought she was upstairs.

$\mathrm{X}$ : No, nother, not Francine. I mean Jennifer.

\section{[b]}

$\mathrm{X}$ : She went out.

Y: He did? I thought she was upstairs.

$\mathrm{X}$ : No, nothim, not Francine. I mean Jennifer.

Esse diagrama mostra também claramente que, em línguas tais como o inglês, o gênero faz parte do dispositivo metapragmático, de onde resulta a coerência da denotação e da predição: isso quer dizer que o gênero funciona não somente sobre o plano pragmático e semântico, mas sobre o plano metapragmático, ele se apoia sobre essas duas dimensões linguísticas - habitualmente de maneira inconsciente-para ligar e conferir coerência ao ato de comunicação. Isso está bem ilustrado na multivocalidade do signo-função de "ela" no Diagrama 1. No seu uso em inglês, médio, corrente, 
23 Ver SILVERSTEIN, 1985

${ }^{24}$ Ver William LEAP, 1995; Ana LIVIA and Kira HALL, 1997; and Naoko OGAWA and Janet SMITH, 1997. heteronormativo, "she" ["ela"] comunica uma multiplicidade complexa de sinais semânticos (número, pessoa, gênero), indexicalizando sob o plano pragmático o signo ao contexto. Mas "she" é também capturado pelo trabalho da metapragmática, que regulamenta a indexicalidade pragmática em curso para fazer um texto coerente interpretável e um evento interlocutório. Mudar o aspecto do gênero, conservando o número e a pessoa - passando a "he" ["ele"] ou "it" [o neutro] ou ainda empregando aleatoriamente o "she", o "he" e o "if" - pareceria fazer perder toda a significação diante do sentido e do valor do texto. Assim, o gênero serve de material de construção de ligações delicadas e íntimas da sociedade humana, mas não no sentido habitual: o gênero liga delicadamente os textos conversacionais e gramaticais aos seus contextos internos e externos - ligando, ou parecendo ligar, uma pessoa a outra. As críticas conservadoras aos estudos linguísticos feministas percebem, mas diagnosticam mal, essa função metapragmática da estrutura linguística, já que tais críticas acusam as feministas ou os/as ativistas homossexuais de incoerência ou coisa pior. Elas não estão erradas se nos atermos a este sentido limitado: em inglês padrão supostamente heteronormativo, a coerência semântica e pragmática depende da ordem indexical formal das categorias gramaticais de gênero, ainda que elas sejam carregadas de ideologia. ${ }^{23}$

Percebe-se, no entanto, rápido o suficiente, que todos os segmentos "coerentes" da linguagem são de fato discursos metapragmáticos implícitos integrados às instituições sociais dominantes ou minoritárias, formais ou informais. O Diagrama 1 mostra que, em inglês, a recusa de se submeter às regras normativas do uso de pronomes parece somente tornar deformado, disfuncional, o sentido de uma conversação inglesa média, na medida em que ele é o contrário da norma, senão antinormativo. De fato, ele veicula o discurso implícito metapragmático da heteronormatividade com suas instituições e, no curso do mesmo processo, ele constrói de novo gêneros no discurso com seus sujeitos de enunciação. ${ }^{24}$

\section{"Poderia ser menina": a emergência linguística do gênero e da sexualidade}

Recentemente, a pesquisa acadêmica sobre linguagem, gênero e sexualidade tem procurado compreender como esses discursos e funções semânticas, pragmáticas e metapragmáticas pressupõem, produzem e regulamentam o gênero e as subjetividades sexuadas, as instituições sociais do trabalho e da intimidade, e os desejos e expectativas normativas. Três grandes séries de questões têm aparecido nesses trabalhos: (1) como gênero e sexualidade emergem 
${ }^{25}$ HALL and O'DONOVAN, 1996 p. $229-230$

${ }^{26}$ Como em Yana; ver Edward SAPIR, 1985.

${ }^{27}$ Theodor STREHLOW, 1944, 1947.

28 De acordo com Baldwin SPENCER, 1927, p. 582.

${ }^{29}$ Ver, por exemplo, Gilbert HERDT, 1994; Michael TAN, 1995; Niko BESNIER, 1998; and Randolph TRUMBACH, 1994. da estrutura (semântica), do uso da língua (pragmática) e da socialização e da ideologia inerentes à linguagem (discursos metapragmáticos)?; (2) como podemos conceituar as relações entre subjetividade e textualidade enquanto ordem de fenômenos?; e (3) como esses traços linguísticos de gênero e sexualidade estão implicados na regulação e contestação dos espaços corporais, institucionais e cotidianos? Veremos que, para responder a essas questões, em princípio é preciso distinguir entre: os elementos linguísticos que codificam as características de gênero em si; as características linguísticas que sinalizam as diferenças de indexação, mas que não são semânticas como tais; e a subjetividade como ordem de fenômeno analiticamente distinta das ordens semântica e (meta)pragmática da linguagem. Comecemos pela questão de saber como os elementos linguísticos codificam as características de gênero.

Temos uma ideia sobre o quanto as línguas sinalizam o gênero das locuções nominais e de seus referentes através de diversos prefixos, sufixos e partículas. Nas numerosas línguas europeias, partículas ou pronomes anafóricos preenchem essa função ("la" em francês, "she" em inglês). Outras línguas sinalizam o gênero por meio de inflexões verbais ou adjetivais (por exemplo, o "gênero morfológico" do hindi). ${ }^{25}$ Em outras línguas, ainda prefixos e sufixos especificam o gênero do/a locutor/a e o da pessoa a que ele/a se dirige. ${ }^{26}$ Nem todas as línguas dividem as classes de nomes segundo o gênero gramatical, como está em questão aqui. Nós temos à mão o exemplo oportuno da língua aranda. Nessa língua, os nomes são classificados em humanos sem gênero, em agentes animados e inanimados. ${ }^{27} \mathrm{O}$ gênero não é um traço semântico ausente do aranda. Os membros das classes humanas e animadas são suscetíveis de serem modificados pelo não marcado (orea, masculino), o marcado (mala, feminino) e duas formas neutras. Os pronomes e os termos de parentesco aranda marcam também o gênero, assim como o fazem os termos relativos a rituais e a maturação física, quando certos estados de desenvolvimento são alcançados (Diagrama $2^{28}$ ).

Infelizmente, a maior parte dos estudos antropológicos sobre gênero e sexualidade não ligam o gênero das locuções nominais com os outros sentidos e níveis semânticos, e não estudam em detalhes a dialética entre estrutura e função semântica e pragmática (tal como a dialética interacional, que foi discutida anteriormente sobre o Diagrama 1). Em contrapartida, a maior parte dos estudos sobre língua e gênero, seja os vindos da linguística ou de outros domínios, consideram bastante superficialmente os gêneros e os sexos - três sexos e quatro gêneros, dois sexos e três gêneros, um sexo e dois gêneros. ${ }^{29}$ Ainda que esses estudos sugiram a 


\section{Diagrama 2}

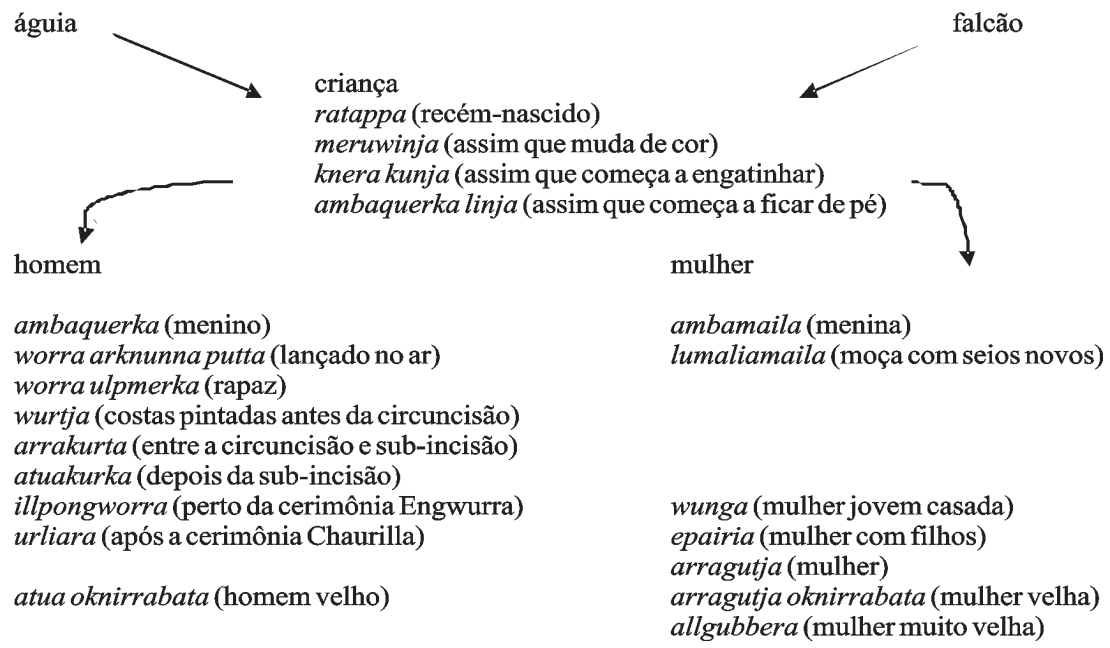
30 Ver Harriet WHITEHEAD, 1993;
and Will ROSCOE, 1994. existência de numerosas variações entre as estruturas linguísticas, a hipótese fundamental de Lacan, que quer que todos os humanos tenham passado pelas forças caudinas do gênero gramatical, não parece ameaçada. Todas as línguas parecem codificar o gênero de uma maneira semântica e indiciar o gênero semântico na diferença corporal humana. São os aspectos sociológicos e pragmáticos dessas categorias semânticas que variam: as relações que imaginamos entre sexo/gênero e sexualidade; a importância do sexo/gênero em relação a outras funções sociais; as variações na regulação institucional daquele que está convocado ao gênero e à sexualidade; e, enfim, a durabilidade dessa convocação - de sociedades nas quais se pode circular entre as diferentes classes do sexo e do gênero com um mínimo de mediação ritual até sociedades nas quais esse movimento é altamente ritualizado. ${ }^{30}$ Parece então que a afirmação de Lacan deve ser contestada, não porque ela presume que a diferença sexual é um traço universal da estrutura das línguas, mas, por um lado, porque ela ignora os meios gramaticais pelos quais as línguas sinalizam a diferença sexual (por exemplo, a língua aranda parece colocar em evidência o tipo de agente mais que o gênero do agente nas suas locuções nominais) e, de outro lado, porque ela supõe que as características pragmáticas da linguagem e do sujeito podem ser suscitadas dos aspectos semânticos da linguagem. Para compreender como gênero e sexualidade emergem da língua enquanto sentidos, significações e 
${ }^{31}$ Encontra-se uma exposição sobre os "dêiticos de gênero" em Sally MCCONNELL-GINET, 1988 Sobre sua função enquanto "dêiticos sociais", ver Penepole ECKERT, 1993; LEVINSON, 1983 p. 89; OCHS, 1992, p. 338 SILVERSTEIN, 1995, p. 280-284 estados, religados a categorias e à subjetividade, é preciso uma metodologia e uma teoria que considerem a linguagem em todas as suas dimensões (estrutura e uso), e devemos reconsiderar a questão do sujeito em relação a essas dimensões.

Pode-se começar distinguindo entre as propriedades indexais e semânticas dos sinais. Por exemplo, como bem sabido, numerosas línguas humanas naturais comportam muitos registros em que o gênero é marcado - duas maneiras ou mais de "dizer a mesma coisa" associando-a aos homens ou às mulheres num grupo social pela marca morfológica, lexical ou sintática. Os homens e as mulheres "dizem a mesma coisa" em termos de denotação e predicação, mas no decorrer do enunciado, indexam o gênero (e, frequentemente, a posição social) do/a locutor/a e do/a interlocutor/a. ${ }^{31} \mathrm{~A}$ existência desses registros marcados e a multivocalidade das funções e das características de seus sinais não nos ajudam a compreender como eles vieram a surgir como tais, nem como eles vieram a ser associados a aspectos particulares dos seres sociais, nem, enfim, como eles se mantiveram tais quais no tempo. A fim de compreender como esses registros marcados por gênero e sexo vieram a surgir e, correlativamente, como eles puderam ser modificados, é preciso de início distinguir entre o excesso de non sense pragmático sempre contido em cada ato de fala (que formula o texto interacional) e o conjunto de discursos metapragmáticos implícitos e explícitos em curso que afirmam como esse material indexical deve ser organizado nas ordens maiores de textualidade. De um lado, temos as características e as funções dos sinais que são correntemente utilizados, implicitamente e explicitamente, para modelar a linguagem no texto normativo, e, de outro lado, temos esses sinais que podem servir para encorajar ou desencorajar esses usos normativos da linguagem.

Todas essas funções e formas pragmáticas e metapragmáticas com seus sentidos e valores semânticos são dados linguísticos "neutros", ainda que densamente saturados no plano ideológico, que se apresentam a qualquer momento no espaço-tempo social. Utilizo o termo "neutro" para lembrar que essas funções e formas são arquiteturas semióticas sem intenção. Elas são talvez o material explícito e implícito sobre o qual baseamos nossos pressupostos sociais - o fundamento sobre o qual produzimos sentido e significação. Entretanto, esses fatos linguísticos existem, simplesmente. $\mathrm{E}$, na medida em que existem, pode-se arrolá-los em novas formas discursivas. O trabalho social que eles conseguem realizar é o resultado que emerge do uso no curso das interações, um uso mediatizado pelas instituições. Parafraseando Ochs, eu diria que o uso cambiante das variantes linguísticas deve tornar-se convencional antes que elas possam funcionar 
como dêiticos de gênero (ou de qualquer outra categoria social). A diferença de gênero deve resultar de uma diferença semiótica, linguística e corporal transformada em ideologia de gênero: o "isto deve ser" da normatividade corporal e vocal, o "como" em "veja como a linguagem e as técnicas do corpo devem se articular, em qual lugar, para qual objetivo".

O espaço colocado pela denotação e pela indexicalidade chega à categoria de função social pelo intermédio de agentes sociais que, muitas vezes sem saber, se valem da função metapragmática da linguagem e de um aspecto ou outro dos signos gramaticais para ordenar as atualidades indexais e semânticas nos registros marcados por gênero (ou tipos de discurso marcados por gênero), que são de uma ordem superior. Esses tipos de discurso fazem então parte dos meios pelos quais cobrimos o sujeito com o "como", "quem", "quando" e "onde" da linguagem apropriada ao gênero e, em consequência, à significação e ao uso apropriados dos espaços sociais variados (públicos, privados, íntimos, sagrados, profanos). Os aspectos modais, qualificadores, quantitativos, negativos ou outros da linguagem constituem uma parte delicada do dispositivo da normatividade de gênero e de suas contestações. Essas funções gramaticais sustentam os meios indiciadores ou fazem elas mesmas parte desses meios graças aos quais são criados novos registros marcados por gênero. Mas o fato de que a indexicalidade sem sentido esteja verdadeiramente em uso para colocar em jogo (ter por consequência) um real espaço semântico ou social ou o fato de que as estruturas correntes de sentido e de significação sejam transformadas em novos sentidos e significações, esses excessos e estruturas pragmáticas ainda existentes, fornecem sempre e já os meios de novos potenciais espaços sociais.

Os estudos que se interessam pela socialização da linguagem, pela ideologia linguística e pela dominação simbólica dizem claramente que a linguagem é uma técnica simbólica estratégica por meio da qual os indivíduos são designados a ordens sociais hegemônicas caracterizadas por gênero e, por esta razão, ele constitui uma posição-chave de luta social. Entre os trabalhos de pesquisa mais interessantes sobre linguagem e gênero, alguns estudaram os processos sociais nos quais o discurso e as funções linguísticas vêm a fazer parte integrante das lutas sociais, a propósito dos papéis e dos valores de gênero e de sexo. Infelizmente, a maior parte desses trabalhos se interessou exclusivamente pelos discursos metapragmáticos que associam homens e mulheres às maneiras de falar, sem explorar como gênero e sexualidade apareceram em todo mundo no espaço-tempo colonial e pós-colonial. Para descrever como o gênero e a sexualidade apareceram nesses contextos, retornemos à conversa entre 
Spencer, Gillen e os Aranda; ela nos servirá para ilustrar a maneira como as pessoas são chamadas a figurar nas ordens sociais marcadas por gênero. Examinemos em particular como esses homens transpuseram as estruturas semânticas de uma língua a outra ao discutirem rituais. Como gênero e sexualidade foram transportados do aranda para o inglês? Compreender o modo de transmissão de gênero (e de sexualidade) nos ajuda a compreender as relações entre gênero (e sexualidade), subjetividade e linguagem? Como Spencer e Gillen contribuíram para a emergência de uma "entidade de ação" ocidental (ato sexual, gênero e sexualidade enquanto qualidades essenciais e duráveis dos humanos ao invés de qualidades acidentais de objetos ao passarem por diversos estados) a partir das ordens gramaticais e pragmáticas indígenas por meio da simples prática que consiste em apontar o dedo e do simples desejo de compreender qualquer coisa a respeito das práticas rituais locais?

É óbvio que os Aranda não falavam só entre eles, nem só com outros grupos aborígenes regionais. Os Aranda, assim como Spencer e Gillen, tentavam se comunicar, lançando pontes entre ordens semióticas sensivelmente diferentes, em condições de poder, de exploração e de dominação sempre brutais em tempo real. Baldwin Spencer tinha chegado à Austrália crendo que Frank Gillen falava aranda fluentemente, mas descobriu que seu "conhecimento de aranda (e várias outras línguas aborígenes) era de fato bem menos fluente que Spencer tinha presumido." 32 Assim, esses ingleses se comunicaram com os Aranda e os grupos vizinhos servindo-se de um crioulo de base inglesa. Quando eles falavam com os homens aranda sobre suas práticas rituais, Spencer e Gillen utilizavam para se exprimir provavelmente frases do tipo: "por que vocês fizeram aquilo durante seus rituais?" ("whatfor youbela doim datun langa corrobboree?"), apontando o dedo ou desenhando no papel ou no chão os atos que eles tomavam como atos sexuais ou, talvez, servindo-se de uma palavra aranda local que eles pensavam querer dizer "copulation". E sem dúvida os homens aranda lhes responderam com uma frase do tipo: "esse negócio agora era a mesma coisa no Alcheringa, não se pode faltar com esse negócio, não se pode fazer errado, la parure da cabeça fica bem ligada à cabeça" ("dat business now, im been same longa Alcheringa, im same, cant missim step datun, cant mistake, im properly stuck longa head", cujo texto se tornaria "a complacência sexual, que era uma prática do Alchenringa, impede que o que quer que seja vá mal durante o ritual; por exemplo, torna-se impossível que os ornamentos de cabeça se soltem e desarranjem durante a cerimônia"). Mas se o "sexo" mantém os ornamentos sobre a cabeça, ele só o faz depois que 
aquilo (ou seu equivalente em crioulo inglês) tenha ligado dois campos semânticos muito diferentes, quer dizer, antes que os dois sistemas semânticos tenham podido se coordenar de maneira concreta e significante (Diagrama 3 ).

\section{Diagrama 3}

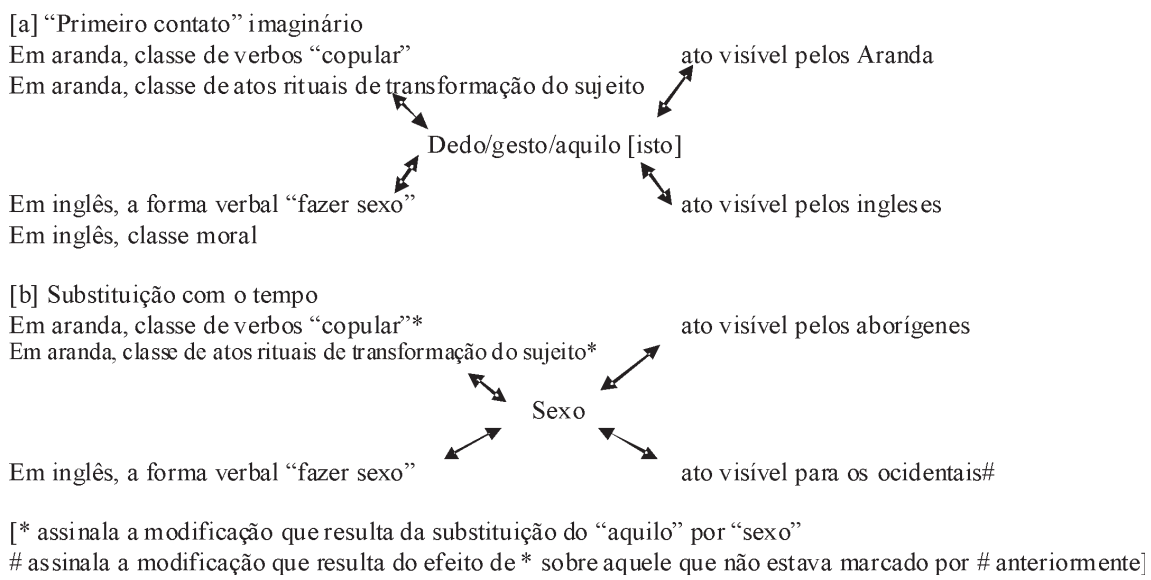

Retomemos novamente o objetivo e nos detenhamos sobre aquilo que podemos considerar como a mais ínfima, senão a mais insignificante, das trocas coloniais: a substituição histórica e gramatical da palavra "sex" pela palavra "that". Num momento qualquer do tempo, seja antes ou depois da chegada de Spencer e Gillen na Austrália Central, sinais indexais tais como apontar o dedo ou outros gestos demonstrativos tinham aberto um canal de comunicação relativamente coerente entre os Aranda e os colonos europeus. Esses sinais indexais ligavam dois universos semânticos muito diferentes, vinculando a princípio cada um desses universos semânticos a um ponto de referência convencionado. Mais uma vez, no sentido estrito, esse ponto de referência convencionado precedeu todo acordo na construção do sentido. Cada grupo, conforme os pressupostos normativos das estruturas profundas de sua "cultura", trazia para o evento comunicativo o "aquilo deve ser", às vezes consciente ou inconscientemente, que se aplica às coisas, às ações, assim como às modificações que se produzem na passagem de um contexto a outro..$^{33}$ Assim, mesmo esse ponto de referência convencionado deve ter precisado de um momento de ajuste enquanto uma entidade de ação se desligava lentamente do campo de ação local rico de conteúdo semântico e pragmático.

Enquanto Spencer e Gillen designavam a ação que eles consideravam como "sexual" - apontando o dedo, com 
a ajuda de um desenho ou do pronome demonstrativo "aquilo" ["that"] - o dêitico "aquilo" era lentamente substituído por "sexo" com suas funções indexais e simbólicas. Em outras palavras, enquanto os Aranda procuravam compreender ao que se referia "aquilo", "aquilo" se incorporava lentamente às estruturas que elaboram o sentido das vidas Aranda e construía um ponto que o "sexo" poderia ultrapassar. Tenha sido ou não na presença deles, os Aranda discutiram o que as questões de Spencer e Gillen poderiam realmente querer dizer, como suas questões se deixavam converter em concepções europeias sobre os humanos e seus ambientes, e o que eles poderiam ou não explicar a respeito das regras cerimoniais, dada a "etiqueta" das relações inter-étnicas. Pouco a pouco, os domínios que eles tinham excluído da troca compreenderiam os próprios atos que tanto fascinavam Spencer e Gillen - a sexualidade ritual, a sexualidade em público, a sexualidade fora da instituição do "casamento" monogâmico. E, com o tempo, os espaços físicos e corporais seriam reorientados e habitados diferentemente. A sexualidade designaria um espaço e relações sociais não em termos rituais, mas em termos associados ao sexo, à intimidade, à privacidade, à vergonha, à excitação.

Substituir "sexo" por "aquilo" não era somente substituir um nome por um pronome demonstrativo, mas um sistema de sentido por outro. O "sexo" iria progressivamente rearticular a ordem inteira da significação semântica e pragmática indígena, iria inserir no texto referências e predicados carregados de valores, esses "onde", "quando", "com quem" (ou o que) e "por que", e carregar como significação alguns aspectos derivados da compreensão britânica dos atos sexuais normativos e não normativos. Isto feito, o próprio espaço veio a se remodelar, o ritual era menos físico, o íntimo uma propriedade privada, o público a mão escondida do poder. No decorrer dessas interações sociais em tempo real, "that" aparece de repente como um gancho gramatical, o meio de ligar um sistema semântico e pragmático a outro, um instrumento de junção, o prelúdio da disciplina corporal proferida como meio pragmático de escapar da violência física. À luz dessas práticas pragmáticas, a questão "por que você faz aquilo?" se distancia do seu referente primeiro e é ressignificada como comentário metalinguístico sobre a arte e a orientação da tradução no contexto colonial.

Essa ressignificação é ainda assim mascarada pelas estratégias de entextualização de Spencer e Gillen. A sexualidade aumenta sua capacidade de produzir um sentido aparentemente natural e universal porque Spencer e Gillen se servem de convenções para reportar o que foi dito, parar citar direta e indiretamente de tal maneira que eles parecem indicar que os Aranda são os autores das práticas referenciais 
${ }^{34}$ Richard PARMENTIER, 1993, p. 263.

${ }^{35}$ Ver Craig CALHOUN, 1995.

${ }^{36}$ Ver Ernesto LACLAU and Chantal MOUFFE, 1985, especialmente $p$. 85-88.

${ }^{37}$ Ver BAKHTIN, 1986, p. 65. que eles procuravam compreender. Richard Parmentier nos lembra que "a citação do discurso de autoridade se rende apenas momentaneamente à posição hierárquica inerente ao discurso reportado, visto que essas palavras oficiais ou tradicionais são de fato colocadas em usos não intencionados por seus autores ou não implicados em seus contextos iniciais". ${ }^{34}$ Spencer e Gillen se servem de citações diretas e indiretas, em grande parte para assinalar a natureza cientíica e liberal de suas conversações com os Aranda e seus vizinhos.

Mas as conversações das quais os Aranda participavam nada mais fazem do que simular o ideal liberal de um evento de comunicação racional, que se extrai de um campo de força. Os Aranda estavam muito conscientes de que um aspecto do poder colonial se justapunha a outra força colonial igual e oposta. Os Aranda e seus vizinhos dançavam e falavam, mas eles estavam no centro de uma exterminação sistemática: roubavam-se, perdiam-se e destruíam-se seus objetos rituais, tomavam-lhes suas terras e, com elas, os recursos materiais e espirituais necessários à vida. Eles tinham dado permissão para registrar seus rituais, e em troca Gillen e Spencer Ihes ofereciam alimento e uma proteção contra as forças da polícia e dos colonos. Visivelmente, a força não estava ausente da cena. Ao contrário. A força era a condição verdadeira da comunicação. ${ }^{35} \mathrm{~A}$ enorme desigualdade na distribuição do poder dava aos Aranda o impulso de adaptar, mesmo de modo muito sutil, seus enunciados ao contexto ao qual Spencer e Gillen estavam associados e que eles contribuíam para criar. E esse poder incitou os Aranda a separar, ainda que de uma maneira ínfima no começo, um segmento de seu mundo/vida semiótico e a utilizá-lo ("that" - "sex") como forma de estabelecer uma linguagem comum e mais ou menos coerente entre eles e esses europeus.

Fazer um balanço desses eventos de interlocução aparentemente menores e suas estruturas semânticas permite, pelo menos num primeiro momento, construir um modelo mais sutil da hegemonia sexual, da manutenção ou da emergência de sistemas normativos novos, passando pela articulação de elementos dessemelhantes nas interações sociais em tempo real. ${ }^{36}$ Essas "enunciações com seus tipos" são "correias de transmissão" que nos permitem desenvolver uma metodologia mais rigorosa para operar entre eventos e ordens de dominação social que procedem de escalas amplamente diferentes. ${ }^{37}$ E elas nos lembram que as instituições de poder fazem sempre parte das condições tácitas, subjacentes e pressupostas das práticas corporais e de comunicação.

\section{O sujeito da linguagem}

Quais são então as relações entre gênero, compreendido de maneira metapragmática, subjetividade e desejo? 
${ }^{38}$ Ver SILVERSTEIN $(1993$, p. 34 ) sobre a interpretação possível para as funções das ordens de fenômenos semânticos e metapragmáticos como sendo distintos um do outro "[em] características muito essenciais".
Para responder a essa questão, é importante considerar a subjetividade como uma ordem de fenômeno distinta dessas da semântica e da pragmática. Essa distinção deixa entrever o limite das teorias contemporâneas de meta-semiótica em relação ao sujeito da linguagem (dotado de gênero e de sexo). ${ }^{38} \mathrm{O}$ "sujeito da linguagem" do qual eu falo não é a matéria da linguagem. Trata-se, sobretudo, de uma referência ao sujeito humano, que é produto da linguagem, e à linguagem enquanto produto dialético porque meio de comunicação, instrumento ou invenção de sujeitos humanos.

Permitam-me que eu resuma brevemente a abordagem da antropologia da linguagem no que se refere ao sujeito. Como já apontei antes, sociolinguistas e antropólogas/os da linguagem passaram ao largo da relação formal entre estados pré e pós-linguísticos e, assim, ao largo do sujeito humano com seu gênero. Mas eles/as também colocaram entre parênteses a questão de saber como as línguas naturais dos humanos, nas suas dimensões pragmáticas e semânticas, conservam a marca de seu status de língua humana. Linguistas não se colocam esta questão: as condições fenomenológicas que fazem com que a linguagem constitua o meio comunicacional dos seres que se tornam sujeitos falantes deixam sua marca sobre as estruturas e suas funções? A compreensão que Silverstein tem das relações entre as ordens semânticas e pragmáticas dos fenômenos linguísticos nos provoca à importância dessa questão e expõe o dispositivo conceitual que exige que a respondamos, pois, se se aceita que uma ordem semântica não seja possível senão por meio de um ato de linguagem qualquer (ou seja, que seja inferida por meio de atos pragmáticos e metapragmáticos), as ordens pragmática e metapragmática de uso da linguagem humana natural implicam da mesma maneira um sujeito fazendo uso dessa linguagem, e um sujeito que um dia não sabia fazer uso da linguagem. Como linguagem, gênero e desejo poderiam reaparecer do ponto de vista desse sujeito? Permitam-me que eu sugira aqui o que está em jogo nessa mudança de perspectiva, em que se passa do ponto de vista do signo para o ponto de vista do sujeito, abordando de início a ruptura na coesão entre linguagem e contexto na perspectiva do sujeito.

A linguagem não pode controlar o contexto de maneira exaustiva, em parte porque o contexto é resultado do conjunto sempre movente dos sistemas denotativos e predicativos de um grupo. Na perspectiva semiótica (do ponto de vista do signo), as pressuposições e as implicações denotativas e predicativas de um indivíduo divergem sempre daquelas dos outros membros de um mesmo grupo linguístico, mesmo que seja de maneira infinitesimal. Todos os sujeitos de um 
${ }^{39}$ LEE, 1997, p. 57.

${ }^{40}$ Sobre performatividade, ver John L. AUSTIN, 1962 e 1979. Sobre gênero e performativo, ver Judith BUTLER, 1990; and LIVIA and HALL, 1997. grupo linguístico são certamente assujeitados à sua língua, mas não de maneira idêntica. Como nota Ben Lee, contudo, "propriedades indexais criativas dos performativos carregam as condições que fazem os enunciados verdadeiros"; ${ }^{39} \mathrm{O}$ performativo não tem sucesso em criar as condições que a tornam verdadeira sem reserva, excessos ou restos. ${ }^{40} \mathrm{O}$ performativo não pode saturar o contexto, pois, como todo ato de linguagem, ele está ligado a numerosas diferenças, ainda que delicadas, no fundamento pressuposto dos sujeitos, fundamento que serve aos sujeitos na avaliação dos eventos, incluindo aí sua felicidade performativa. A garrafa jamais bate no barco, o percussionista sagrado jamais bate o tempo todo, se se presta atenção às pressuposições e às expectativas necessariamente variadas de cada um daqueles que, na multidão, se mostram ou olham. Eles marcam o ritmo "suficientemente bem", "melhor que da última vez", "de uma maneira que podemos aprovar", "quase perfeitamente, mas você reparou nos sapatos dela!", "bem, é verdade que ela não deveria usá-los, mas isso não tem importância, né?".

A origem dessas diferenças nas pressuposições pode se explicar, ao menos em parte, em termos puramente semióticos. Como já mencionei antes, os componentes dos novos registros são provenientes das formas e funções pragmáticas, semânticas e metapragmáticas, quaisquer que sejam, que constituem o material linguístico de uma comunidade de locutoras e locutores. Todos os "tipos de interação", "tipos de identidade social", "tipos de estado de agente associado ao tipo de identidade social" possíveis, e todos os meios semânticos e pragmáticos pelos quais esses tipos são instituídos fornecem às locutoras e locutores os materiais que inserem um gênero do discurso no domínio de outro e que criam assim novos gêneros do discurso e textos. Essas entextualizações podem ser o resultado do trabalho intencional de um sujeito criativo, as visões de um psicótico ou fazer parte de um movimento social. De toda maneira, um registro normativo é inserido num outro e, no curso desse processo, ressignifica o contorno discursivo inteiro da comunidade de fala.

A entextualização é um traço corrente da linguagem que usam todos os dias as locutoras e locutores que a empregam nas funções metapragmáticas para articular aquilo que fazem, onde e com quem. A natureza cotidiana dessa cartografia e recartografia semiótica constitui uma parte crítica do conflito social. Por exemplo, as feministas utilizaram os ideais e expectativas cotidianas sobre a maneira como os "humanos" ou as "pessoas democráticas liberais" deveriam se falar umas às outras, para ressignificar as expectativas e ideais normativos sobre a maneira como as mulheres e os 
${ }^{41}$ Jürgen HABERMAS, 1993; Lauren BERLANT, 1997; Miriam HANSON 1993; Nancy FRASER, 1993; and Susan GAL, 1998.

${ }^{42}$ Ver LEVINSON, 1983, p. 97-166; and LACAN, 1977b.

${ }^{43} \mathrm{Em}$ francês também na versão em inglês. [Nota da tradutora]

${ }^{44}$ Susan Gal observou que esses mapeamentos através de registros discursivos estão sempre já implicados em estruturas de poder. Ela observa que, embora "a habilidade de fazer outros aceitarem e agirem conforme a representação de mundo de alguém" seja um "aspecto crítico da dominação simbólica..., tal poder cultural raramente fica incontestado", especialmente quando "práticas desvalorizadas propõem ou incorporam modelos alternativos de mundo social"(GAL, 1991, p. 177). Para saber mais sobre negociação de significado, ver Mariorie GOODWIN, 1993; Susan EHRLICH and Ruth KING, 1996; Susan HERRING: Deborah JOHNSON and Tamra Di BENEDETTO, 1995. Para uma discussão socialmente situada do uso de modais na sociedade aborígine, ver Elizabeth POVINELLI, 1993. homens deveriam se falar. Aquilo que diz Habermas sobre a emergência de uma forma particular de subjetividade burguesa liberal no século XVIII na Europa constitui outro exemplo pertinente dessas extensões do gênero, das entextualizações e das refigurações. A livre circulação das informações econômicas sobre longas distâncias no início do capitalismo de mercado conduziu a inovações estéticas nas formas textuais públicas e privadas, e a expectativas sociais subsequentes para saber como o discurso deveria ser instituído no espaço nascente da esfera pública. ${ }^{41}$

Mas se a linguagem dá às locutoras e locutores os meios de produzir textos interativos coerentes, ela lhes fornece também os meios de produzir frases coerentes sobre o plano sintático que colocam em questão as normas sociais e os usos ou lhes fazem elogio. Tomemos por exemplo as frases seguintes perfeitamente gramaticais: "Ele poderia ser um homem" ou "Certos homens são homens", que implicam que "Ao menos um homem não é um homem". ${ }^{42}$ Esses dêiticos sociais podem ou não ter um contexto ou uma referência evidente corporal ou comportamental. Mas eles têm de fato um efeito social. Ao menos, a/o ouvinte se pergunta o que eles significam, "Que você quer dizer: certos homens são homens? O que você disse? Quem ou o que pode fazer com que um homem seja outra coisa que não um homem e em que essa 'outra coisa' consiste? Não. Um homem é um homem. A menos que...". Esse fragmento imaginário de introspecção demonstra uma vez mais que existe simplesmente um espaço divergente entre o gênero normativo gramatical e o social. Isto é, sua atualidade o torna disponível para construir sentido, se os agentes sociais o tomam, o implementam, fazem-lhe qualquer coisa. É o que Lacan certamente fez com suas proposições infames como "La femme n'existe pas" e "ll y a d'l'Un" . ${ }^{43}$ Num primeiro momento, a função pragmática de "certos homens são homens" poderia muito bem abrir uma fina brecha interpretativa na normatividade masculina. Mas, com o tempo, a interrogação silenciosa, muitas vezes debilitante, da questão "Você é isso aí?" pode remodelar as expectativas normativas que se pode assegurar, não somente para a masculinidade, mas para as instituições sociais que estabelecem ou que são estabelecidas por esse gênero. ${ }^{44}$

A própria estrutura linguística dá às locutoras e locutores os meios de assinalar a condicional de todas as ocorrências das estruturas e usos da linguagem, de cada enunciação, seja ela estruturada de maneira normativa ou contranormativa. Note esta sequência de enunciados modais: "Eu deveria talvez falar desse jeito para ser uma mulher, ou talvez eu não devesse"; "Eu sou talvez uma mulher, ou talvez eu não seja"; "Eu não deveria ter feito, mas é agora 
é tarde"; "Aí está o que poderiam ser o bom contexto, as boas condições, as boas pessoas para me exprimir dessa maneira. Mas talvez não sejam". Esses "talvez" e "poderia ser" marcam potenciais "contrários" que locutoras e locutores podem sempre indexar; pouco importa se existe o conteúdo real desse contrário no momento. Quer sirvam para reforçar os regimes linguísticos normativos ou para mostrar o fracasso em curso da normatividade dos gêneros, esses traços gramaticais fornecem as ferramentas concretas do combate social em tempo real. Eles indicam a "condição de incerteza" e, assim, as possibilidades que residem nas estruturas duráveis de pressuposições da linguagem e da sociedade, mesmo se, em primeiro lugar, essa condição de possibilidade não seja nada mais que um espaço gramatical vazio.

A origem desse sentimento de incerteza (ou dessa possibilidade) é em parte o resultado do sentido metapragmático da pessoa que fala: seu sentido de formas alternativas de implícito e de explícito que existem na sua língua e as cartografias metapragmáticas que concedem e devolvem coerência a essas formas. Mas esse sentimento, essa pulsão modal, deriva também de outra ordem de fenômeno: a subjetividade. É certamente verdadeiro que, bem antes que o sujeito (feminino) alcance uma consciência - ainda que parcial - dos efeitos da linguagem, isso aí imprime nela as regras tácitas a respeito do gênero, que se transformam em fortes estruturas pressupostas que ela deve assumir para tornar-se um sujeito-de-enunciação apropriado. A pressuposição e a implicação puramente gramaticais ligadas ao gênero revelam-se ser a condição para se tornar articulado no reconhecível. A designação dos gêneros tem suas consequências: os gêneros são performativos. Em inglês, por exemplo, o gênero gramatical cria o sentido comum adjetival de pelo menos três maneiras: "It makes sense to her", "It makes sense for her", "It makes sense of her".

Ainda assim, enquanto os agentes sociais (parentes, professoras/es, cuidadoras/es, celebrantes de rituais) servem de mediadores/as para impregnar os indivíduos das regras tácitas do gênero, esses últimos impregnam a língua dos traumas e das sensações corporais que eles associam com a intimidade que modela sua vida. Lembrem que, do ponto de vista do sujeito, a estrutura linguística só pode ser inferida por meio das ocorrências pragmáticas e metapragmáticas do uso linguístico. Por exemplo, o sujeito feminino no estado pré-linguístico deve inferir do uso do termo "ele" um sistema de número, pessoa e gênero, o que significa que o sentido e o valor gramatical só aparecem graças às práticas pragmáticas e metapragmáticas de outros sujeitos, e em contextos de riscos no plano da diferenciação para o próprio sujeito feminino pré-linguístico. 
${ }^{45}$ Roman JAKOBSON, 1990, p. 90.

${ }^{46}$ JAKOBSON, 1990, p. 91
Uma interpretação forte de "sujeito da linguagem" argumentaria que as diferentes ordens de fenômenos linguísticos devem transmitir na forma de sinal, na função, a capacidade ou a condição de ser o meio comunicativo de uma forma particular de ser, o ser humano que se torna um sujeito falante. Ainda não entendo claramente como se pode chegar a demonstrar essa marca (empreinte), nem quais implicações se deveria tirar da dificuldade de dar conta metodologicamente do que faz sentido no plano fenomenológico. Mas não nos inquietemos por enquanto com esses numerosos perigos, e tornemos a examinar mais um pouco a questão da modalidade da perspectiva que proponho. Como se sabe, a modalidade marca gramaticalmente o grau de engajamento do/a locutor/a na enunciação que ele/a emite. Mas a modalidade pode também ser considerada como o sinal metalinguístico da dependência da linguagem diante de um sujeito que deve se tornar falante. A forma infantil "pode ser que não" pode assinalar não somente um aspecto lógicosemântico da linguagem, mas antes primeiramente toda experiência de ser treinada por uma forma semiótica encarnando uma condição necessária para "ser" socialmente e, ao mesmo tempo, a experiência de "ser" bem antes desse treinamento. Em suma, a pulsão que Lacan nomeou desejo poderia nem ser gramaticalizada nas formas linguísticas como o humor e os desiderata.

Nomeio "pragmática íntima da pessoa" suas primeiras e subsequentes perturbações e gramaticalizações das normas sociais da linguagem. Roman Jakobson mencionou um fenômeno que está ligado a isso e que ele chamou de "a língua individual" - o código linguístico personalizado demarcado por alguém que evita "certas formas ou certas palavras que são aceitas pela sociedade, mas que parecem inaceitáveis para ele por qualquer razão ou pelas quais ele tem aversão". ${ }^{45}$ Se a "língua social" mantém a unidade da sociedade, a "língua individual" reflete e mantém "a unidade, isto é, a continuidade da identidade individual". ${ }^{46} \mathrm{~A}$ pragmática íntima de uma pessoa incluiria as delicadas estruturas específicas de uma pragmática, tais como a aprendizagem da maneira apropriada e inapropriada de classificar os gêneros, de se referir a eles e de identificá-los; ela incluiria os traços fonológicos ínfimos do registro social que desenha o espaço social no ato de fala. ${ }^{47}$ Mas ela compreenderia também os espectros fragmentários de inumeráveis encontros microdiscursivos e corporais, meiostópicos e traços da memória, esperanças não linguísticas, aspirações, desapontamentos, superfícies corporais e contornos que impregnam os traços fonológicos, as escolhas lexicais, os truques sintáticos. Inversamente, a própria estrutura linguística poderia assinalar o provisório de cada enunciação 
efetiva - segmento de sentido modelado pela metapragmática.

Essas pragmáticas íntimas são cruciais para compreender a dinâmica da sociedade, pois elas desestabilizam a própria língua da comunidade íntima normativa que as instituições que regulam a linguagem deveriam estabilizar. Elas têm essa propriedade porque a pessoa projeta ou, mais precisamente, prolonga sua pragmática íntima sobre cada cena onde ela aparece. Essas pragmáticas íntimas migram, despercebidas, com os indivíduos no momento em que eles entram e transgridem as esferas públicas e íntimas, aí orientando suas expectativas e demandas, o que explica em parte porque ninguém realmente "capta" o que eles tentam dizer. "Por que você não entende o que estou te pedindo? Não falamos a mesma língua?". Rigorosamente falando, a resposta é "não". Mas, uma vez mais, se a resposta é não, não é simplesmente porque a língua social reúne a totalidade das línguas individuais divergentes que a compõem. Rigorosamente, a resposta é não porque a língua não é somente um fenômeno semiótico.

Façamos apelo uma última vez ao caso dos Aranda para mostrar como se situa a dinâmica da pragmática íntima da pessoa nas interações sociais e seu contexto institucional. Em Aranda Phonetics and Grammar, texto escrito cerca de quarenta anos depois de Native Tribes, de Spencer e Gillen, Theodor G. H. Strehlow esboça os grandes traços fonêmicos e gramaticais do Aranda e, ao longo, brevemente, ele dissipa os estereótipos negativos disseminados sobre as línguas aborígenes. Mas Strehlow ficou bem contrariado, na verdade ele ficou um pouco escandalizado por uma característica da língua aranda: a falta de distinções de gênero. "Os nomes aranda não conhecem distinções de gênero: masculino, feminino e neutro são todos termos sem sentido para um homem de uma tribo da Austrália Central. Nem mesmo os animais de caça comuns são diferenciados de acordo com o sexo". ${ }^{48}$ Tudo aquilo que se costuma chamar de relativismo linguístico se desvanece diante da verdade original da diferença dos sexos. No aranda não somente faltavam distinções de gênero nas locuções nominais, mas a pessoa aranda "se recusava a reconhecer em sua gramática a distinção essencial dos gêneros", estado de espírito e da língua que Strehlow negava que pudesse ter sido sempre a mesma.

Se se exclui a questão de saber se a língua aranda marca o gênero e de que maneira ela o faz, pode-se observar que as pressuposições gramaticais do inglês, com suas consequências, estão na fonte do que Strehlow considera como uma condição fundamental da fala humana bem articulada. O sentido metalinguístico da necessidade do gê- 
${ }^{49}$ Veja em ABU-LUGHOD and LUTZ (1990) uma abordagem típica.

${ }^{50}$ Em português, "emoção" é derivada do francês "émotion", a partir de "motion", do latim "motio, onis", "movimento" (Dicionário Aulete Digitaf). [Nota da tradutora] nero em inglês que Strehlow possui se transforma em uma exigência moral que define quais "distinções fundamentais" os humanos devem reconhecer para serem verdadeiros humanos. As estruturas gramaticais diferenciais da língua são aqui reconsideradas como índices da recusa psicótica daqueles lá ao reconhecer a realidade natural da diferença dos sexos. Os Aranda, contudo, poderiam considerar que a classificação totêmica constituía uma divisão social mais pertinente que a diferença sexual (a águia e o falcão), ou ao menos, paralela à diferença sexual (ver o Diagrama 2). 0 desconforto que Strehlow exprime a respeito do destino que os Aranda reservam ao gênero não é nada se comparado ao desconforto que Spencer e Gillen exprimem tentando compreender a significação social do campo de ação que eles concebiam como sendo evidentemente sexo (ritual).

A pragmática íntima de uma pessoa não se volta simplesmente ao próprio código, mas às vezes ao código e aos desejos que ele perturba e que o perturbam de volta. $A$ coleta e a ansiedade de Strehlow não eram somente manifestação do inconsciente whorfiano, a má-compreensão sistemática da sua própria língua projetada sobre a língua aranda. A pragmática íntima de Strehlow o levou de volta à experiência que o tinha feito sujeito da linguagem, com os riscos que esse tornar-se tinha incorrido e ainda incorreriam. Se a língua individual mantém a identidade individual, ela a mantém como cena onde jorra o desejo. Afinal, o que perturba a língua social e a transforma em língua individual não é a linguagem por ela mesma, mas, pelo menos em parte, na interioridade pré e não linguística, os vínculos afetivos e corporais, as necessidades, os imaginários e as superfícies que a linguagem marca/é marcada e contraria/é contrariada. Esses afetos e imaginários são certamente regrados pelo código individual, mas estritamente falando eles não são assimiláveis ao código. Aqui, a psicanálise e as abordagens dominantes da antropologia da linguagem, do gênero e da sexualidade diferem. $\mathrm{O}$ desejo de que fala a psicanálise se distingue. Ele não é uma codificação específica das emoções, sentimentos, categorias emocionais, discursos emotivos ou discurso sobre as emoções. ${ }^{49}$ Ele não se reduz à "codificação linguística" que "constitui um fenômeno distinto e descritível", ao "discurso sobre as emoções", ou ao "discurso emotivo" (função fática), embora tudo isso deixe um traço de seu movimento. A emoção poderia se revelar uma tradução útil do desejo, mas somente se a emoção for compreendida no seu sentido etimológico ${ }^{50}$ de incitação, movimento definido pelo deslocamento, não em direção a alguma coisa específica, mas em direção ao exterior, se distanciando de todo posicionamento; por exemplo, toda posição tal como "eu sou uma mulher", "isto não é sexo", "fazer isso faz prender as decorações na cabeça". 


\section{Conclusão}

Este ensaio procurou sugerir como uma compreensão de inspiração lacaniana da emergência do sujeito na linguagem poderia ser reconceitualizada numa compreensão metassemiótica da linguagem; como as conceitualizações metassemióticas das ordens de fenômenos relacionados com a linguagem poderiam se encontrar modificados; e, em último lugar, como nossa compreensão de linguagem, gênero e poder poderia ser aprofundada e estendida no decorrer desse processo. Isso, creio eu, podemos afirmar com segurança. Ao invés de conceber a estrutura linguística e o gênero social articulando-se claramente em diversos contextos, e esses dois fenômenos semióticos articulando-se claramente ao fenômeno da subjetividade, deve-se compreender que cada ordem está no caminho contínuo de se ligar às outras e às substâncias corporais, seus contextos e referentes ao mesmo tempo pressupostos e implicados. Os discursos e as funções pragmáticas e metapragmáticas fornecem à linguagem meios sutis e vigorosos para assegurar a "fixação" dos textos denotativos aos corpos, aos contextos, às instituições e aos psiquismos. E os corpos, os contextos e os espaços concretos fornecem superfícies, densidades, plasticidades, massas, vazios e solidez com as quais a linguagem está lutando.

Mas uma diversidade de agências e agentes sociais é necessária para ordenar e disciplinar o uso dessas formas linguísticas e não linguísticas, a fim de frear ou precipitar o jogo inerente da inovação linguística e das modificações sociais que dela resultam. Esses agentes e agências incluem nossos/as aliados/as mais íntimos/as, professoras e professores, amigas e amigos, seres amados, que nos impelem a falar como convém enquanto "ele" ou "ela", gay ou hétero, assim como nossos mais distantes contemporâneos, personagens oficiais do mundo da educação ou do Estado que legislam sobre o discurso incitante ou pornográfico na esfera pública,

${ }^{51}$ Ver Catharine MACKINNON, 1993; BUTLER, 1997. no campus, na cidade, na internet e nas correspondências. ${ }^{51}$

No decorrer dessas circunstâncias ordinárias e extraordinárias, nesses espaços íntimos e intimidantes, as crianças e os adultos aprendem não somente o conteúdo particular da dominação/incitação linguística, mas também sua forma específica ("não se fala assim" ou "é assim que você deve dizer"), assim como a diversidade de consequências decorridas por falar de outra forma. Eles/as estendem, então, essa forma de dominação linguística e esses riscos às diversas instituições sociais do trabalho, da intimidade, da identidade de gênero e de sexo. Mas, na medida em que a linguagem possui os meios para se amarrar solidamente aos contextos, ela fornece também aos agentes sociais o lugar e os meios de desatar as amarras indexais de gênero, porque uma forma 
indexical fundamentalmente sem significação molda de dentro o sentido do gênero; cada lugar onde um sujeito falante liga o gênero a um contexto social torna-se também o lugar onde outro sujeito falante pode contestar essa ligação. Inumeráveis estudos de linguagem e gênero já ilustraram a diversidade das formas semióticas, dos conteúdos e das mediações desses combates.

Tornar-se um sujeito da linguagem munido de um gênero implica então um contexto para o sujeito da linguagem e as condições nas quais esse sujeito vai sofrer. Esse sujeito sofrerá por razões puramente linguísticas. As características e funções semânticas, pragmáticas e metapragmáticas, assim como os agentes sociais que orquestram a mediação, ordenam as condições pressupostas da maneira apropriada de ser um sujeito num gênero. Mas essas ordenações de gênero e de sexualidade normativas são sempre sujeitas a modificação, questionamento, interrogação e acusação, baseadas nessas mesmas características, funções, instituições e agentes. A linguagem pode denotar e fixar o gênero, mas ela fornece também os meios sempre presentes de sua insegurança e de sua indeterminação. Mas esse sujeito da linguagem sofrerá também pela linguagem. Condenada a ser atual somente pela linguagem, o sujeito [feminino] será forçado a se enunciar ela mesma enquanto sujeito de uma humanidade plena e inteira se servindo de um meio comunicacional necessariamente parcial e particularizante. O sujeito será forçado a entrar na língua social com uma pragmática íntima que provoca e é provocada por essa língua. Assim, falar como é apropriado para uma mulher, é talvez tornar-se uma mulher apropriada. Mas, se é assim, ser mulher é estritamente impossível. Mas não mais nem menos que para o homem, que com toda a evidência indexical da sua Coisa, sofre do fato e da certeza de seu lugar pragmático.

\section{Referências}

ABU-LUGHOD, Lila; LUTZ, Catherine A. "Introduction: Emotion, Discourse, and the Politics of Everyday Life". In: LUTZ, Catherine A.; ABU-LUGHOD, Lila (Eds.). Language and the Politics of Emotion. Cambridge: Cambridge University Press, 1990.

AUSTIN, John L. How to Do Things with Words. Oxford: Oxford University Press, 1962.

"Performative utterances." In: . Philosophical Papers. Oxford: Oxford University Press, 1979. p. 233-252.

BAKHTIN, Mikhail M. "The Problem of Speech Genres". In: EMERSON, Caryl; HOLQUIST, Michael (Eds.). Speech Genres 
and Other Late Essays. Austin: University of Texas Press, 1986. p. 60-102.

BERGVALL, Victoria; BING, Janet; FREED, Alice (Eds.). Rethinking Language and Gender Research, Theory and Practice. New York; London: Longman, 1996.

BERLANT, Lauren. "Female Complaint". Social Text, n. 19/20, p. 237-259, 1988.

"Introduction: the intimate public sphere." In: The Queen of America Goes to Washington City: Essays on Sex and Citizenship. Durham: Duke University Press, 1997. p. 124.

BESNIER, Niko. "Reported Speech and Affect on Nukulaelae Atoll." In: HILL, Jane; IRVINE, Judith (Eds.). Responsibility and evidence in oral discourse. Cambridge: Cambridge University Press, 1993. p. 161-181.

"Polynesian Gender Liminality through Time and Space". In: HERDT, Gilbert (Ed.). Third Sex, Third Gender: Beyond Sex Dimorphism in Culture and History. New York: Zone Books, 1998. p. 285-328.

BOURDIEU, Pierre. Outline of a Theory of Practice. Cambridge: Cambridge University Press, 1977.

BUCHOLTZ, Mary; HALL, Kira. "Introduction: twenty years after Language and woman's place." In: Gender Articulated: Language the Socially Constructed Self. New York e London: Routledge, 1995. p. 1-22.

BUTLER, Judith. Gender Trouble: Feminism and the Subversion of Identity. New York: Routledge, 1990.

Excitable speech. A politics of the performative. New York e London: Routledge, 1997.

CALHOUN, Craig. Critical Social Theory: Culture, History and the Challenge of Difference. Oxford: Blackwell, 1995.

CAMERON, Deborah. Verbal hygiene. London, New York: Routledge, 1995.

CAMERON, Deborah; KULICK, Don. Language and sexuality. Cambridge: Cambridge University Press, 2003.

COPJEC, Joan. "Sex and the euthanasia of reason." In: Read my desire: Lacan against the historians. Cambridge: MIT Press, 1994. p. 201-236.

CRAPANZANO, Vincent. "Text, transference, and indexicality." In: LUCY, John A. (Ed.). Reflexive Language: Reported Speech and Metapragmatics. Cambridge: Cambridge University Press, 1993. p. 293-314.

" "Lacking now is only the leading idea, that is: we, the rays, have no thoughts': interlocutory collapse in Daniel Paul Schreber's Memoirs of my nervous illness." Critical Inquiry, v. 24, n. 3, p. 737-767, 1998.

De LAURETIS, Theresa. Alice doesn't: feminism, semiotics, cinema. Bloomington: Indiana University Press, 1984. 
DERRIDA, Jacques. "Signature Event Context". In: The Margins of Philosophy. Chicago, University of Chicago, 1982. p. 307-330.

ECHOLS, Alice. "Cultural Feminism: Feminist Capitalism and the Anti-Pornography Movement". Social Text, v. 7, p. 34$53,1983$.

ECKERT, Penelope. "Cooperative Competition in Adolescent 'Girl Talk'”. In: TANNEN, Deborah (Ed.). Gender and Conversational Interaction. Oxford: Oxford University Press, 1993. p. 32-61.

EHRLICH, Susan; KING, Ruth. "Consensual sex or sexual harassment: negotiating meaning." In: BERGVALL, Victoria; BING, Janet; FREED, Alice (Eds.). Rethinking Language and Gender Research, Theory and Practice. New York e London: Longman, 1996. p. 153-172.

ERRINGTON, Joseph J. Structure and style in Javanese: a semiotic view of linguistic etiquette. Philadelphia: University of Pennsylvania Press, 1988.

FRASER, Nancy. "Rethinking the Public Sphere: A Contribution to the Critique of Actually Existing Democracy". In: CALHOUN, Craig (Ed.). Habermas and the Public Sphere. Cambridge: MIT Press, 1993. p. 109-142.

FREED, Alice; GREENWOOD, Alice. "Women, Men and Type of Talk: What Makes the Difference?" Language in Society, v. 25, n. 1, p. 1-26, Mar. 1996.

FREUD, Sigmund. Totem and taboo. New York: Norton, 1989.

GAL, Susan. "Problematics of research on language and gender." In: DI LEONARDO, Micaela (Ed.). Gender at the Crossroads of Knowledge. Berkeley: University of California Press, 1991. p. 175-203.

."Multiplicity and Contestation among Linguistic Ideologies". In: SCHIEFFELIN, Bambi B.; WOOLARD, Kathryn A.; KROSKRITY, Paul V. (Eds.). Language Ideologies, Practice and Theory. New York: Oxford University Press, 1998. p. 229-331.

GOODWIN, Marjorie. "Tactical uses of stories: participation frameworks within boys' and girls' disputes." In: TANNEN, Deborah (Ed.). Gender and Conversational Interaction. Oxford: Oxford University Press, 1993. p. 110-143.

GRAY, John. Men Are from Mars, Women Are from Venus: $A$ Practical Guide for Improving Communication and Getting What You Want in Your Relationships. New York: Harper Collins, 1992.

GROSZ, Elizabeth. Jacques Lacan: a feminist introduction. New York a London: Routledge, 1990.

HABERMAS, Jurgen. The Structural Transformation of the Public Sphere: An Inquiry into a Category of Bourgeois Society. Cambridge: MIT Press, 1993. 
HALL, Kira; BUCHOLTZ, Mary (Eds.). Gender Articulated: Language the Socially Constructed Self. New York e London: Routledge, 1995.

HALL, Kira; BUCHOLTZ, Mary; MOONWOMAN, Birch (Eds.). Locating power: proceedings of the second Berkeley women and language conference. Berkeley Women and Language Group: Berkeley, 1992.

HALL, Kira; O'DONOVAN, Veronica. "Shifting Gender Positions Among Hindi-speaking Hijras". In: BERGVALL, Victoria; BING, Janet; FREED, Alice (Eds.). Rethinking Language and Gender Research: Theory and Practice. London: Longman, 1996. p. 228-266.

HANKS, William F. "Metalanguage and Pragmatics of Deixis". In: LUCY, John A. (Ed.). Reflexive Language: Reported Speech and Metapragmatics. Cambridge: Cambridge University Press, 1993. p. 127-157.

HANSON, Miriam. "Foreword". In: NEGT, Oskar; KLUDGE, Alexander (Eds.). Public Sphere and Experience: Towards and Analysis of the Bourgeois and Proletarian Public Sphere. Minneapolis: University of Minnesota Press, 1993. p. ix-xli.

HARVEY, Keith; SHALOM, Celia (Eds.). Language and Desire: Encoding Sex, Romance and Intimacy. London; New York: Routledge, 1997.

HERDT, Gilbert (Ed.). Third Sex, Third Gender: Beyond Sex Dimorphism in Culture and History. New York: Zone Books, 1994.

HERRING, Susan; JOHNSON, Deborah A.; DI BENEDETTO, Tamra. "This discussion is going too far!: Male resistance to female participation on the internet". In: HALL, Kira; BUCHOLTZ, Mary (Eds.). Gender Articulated: Language the Socially Constructed Self. New York e London: Routledge, 1995. p. 67-96.

HOLMES, Janet. Women, men and politeness. London: Longman, 1995.

IRVINE, Judith. "Registering affect: heteroglossia in the linguistic expression of emotion." In: LUTZ, Catherine; ABULUGHOD, Lila (Eds.). Language and the Politics of Emotion. Cambridge: Cambridge University Press, 1990. p. 126161.

JAKOBSON, Roman. "Langue and Parole: Code and Message". In: WAUGHT, Linda; MONVILLE-BURSTON, Monique (Eds.). On Language, Roman Jakobson. Cambridge: Harvard University Press, 1990. p. 80-109.

KEATING, Elizabeth. "Language, Gender, Rank and Social Space: Honorifics in Pohnpei, Micronesia". In: BUCHOLTZ, Mary. (Ed.). Cultural Performances: Proceedings of the Third Berkeley Women and Language Conference. Berkeley: Berkeley Woman and Language Press, 1994. p. 367-377. 
KRISTEVA, Julia. Language in desire: a semiotic approach to literature and art. New York: Columbia University Press, 1980.

KULICK, Don. Travesti. Chicago: University of Chicago Press, 1998.

LACAN, Jacques. "The signification of the phallus." In: Ecrits: a selection. New York: Norton, 1977a. p. 281-291.

"The Agency of the Letter in the Unconscious or Reason since Freud". In: Ecrits: a selection. New York: Norton, 1977b. p. 146-178.

LACLAU, Ernesto; MOUFFE, Chantal. Hegemony and socialist strategy. London; New York: Verso, 1985.

LEAP, William (Ed.). Beyond the Lavender Lexicon: Authenticity, Imagination and Appropriation in Lesbian and Gay Languages. Buffalo: Gordon and Breach, 1995.

LEE, Benjamin. Talking Heads: Language, Metalanguage, and the Semiotics of Subjectivity. Durham; London: Duke University Press, 1997.

LEVINSON, Stephen C. Pragmatics. Cambridge: Cambridge University Press, 1983.

LIVIA, Anna; HALL, Kira (Eds.). Queerly Phrased: Language, Gender and Sexuality. Oxford: Oxford University Press, 1997.

LUCY, John A. (Ed.). Reflexive Language: Reported Speech and Metapragmatics. Cambridge: Cambridge University Press, 1993.

LUTZ, Catherine. "Engendering emotion: gender, power and rhetoric of emotional control in American discourse." In: LUTZ, Catherine; ABU-LUGHOD, Lila (Eds.). Language and the Politics of Emotion. Cambridge: Cambridge University Press, 1990. p. 69-91.

LYONS, John. Semantics. Cambridge: Cambridge University Press, 1977.

MACKINNON, Catharine A. Only Words. Cambridge: Harvard University Press, 1993.

McCONNEL-GINET, Sally. "Language and Gender". In: NEWMEYER, Frederick J. (Ed.). Linguistics: The Cambridge Survey. Cambridge: Cambridge University Press, 1988. v. IV. Language: The Social-Cultural Context. p. 75-99.

MILLS, Sara. Language and gender: interdisciplinary perspectives. London e New York: Longman, 1995.

MITCHELL, Juliet. "Introduction - 1". In: MITCHELL, Juliet Mitchell; ROSE, Jacqueline (Eds.). Feminine sexuality: Jacques Lacan and the école freudienne. New York e London: Norton, 1985. p. 1-26.

MULVANEY, John; MORPHY, Howard; PETCH, Alison (Eds.). 'My Dear Spencer': The letters of F. J. Gillen to Baldwin Spencer. Melbourne: Hyland, 1997.

234 Estudos Feministas, Florianópolis, 24(1): 205-237, janeiro-abril/2016 
OCHS, Elinor. Culture and Language Development: Language Acquisition and Language Socialization in a Samoan Village. Cambridge: Cambridge University Press, 1988. . "Indexing Gender". In: DURANTI, Alessandro; GOODWIN, Charles (Eds.). Rethinking Context: Language as an Interactive Phenomenon. Cambridge: Cambridge University Press, 1992. p. 336-358.

. "Linguistic Resources for Socializing Humanity". In: GUMPERZ, John J.; LEVINSON, Stephen C. (Eds.). Rethinking Linguistic Relativity. Cambridge: Cambridge University Press, 1996. p. 407-437.

OGAWA, Naoko; SMITH, Janet S. "The Gendering of the Gay Male Sex Classing in Japan. A Case Study Based on Rasen No Sobyo". In: LIVIA, Anna; HALL, Kira (Eds.). Queerly Phrased: Language, Gender and Sexuality. Oxford: Oxford University Press, 1997. p. 402-415.

PARMENTIER, Richard J. "The Political Function of Reported Speech: A Belauan Example". In: LUCY, John A. (Ed.). Reflexive Language: Reported Speech and Metapragmatics. Cambridge: Cambridge University Press, 1993. p. 261-286.

PHILIPS, Susan; STEELE, Susan; TANZ, Christine (Eds.). Language, Gender and Sex in Comparative Perspective. Cambridge: Cambridge University Press, 1987.

POVINELLI, Elizabeth A. “'Might be something': the language of indeterminacy in Australian Aboriginal land use." Man, v. 28 , n. 4, p. 679-704, dez. 1993.

The cunning of recognition: indigenous alterity and the making of Australian multiculturalism. Durham: Duke University Press, 2004.

ROHEIM, Geza. Psychoanalysis and anthropology. New York: International Universities Press, 1973. 1974.

Children of the desert. New York: Harper and Row,

ROSCOE, Will. "How to Become a Berdache: Toward a Unified Analysis od Gender Diversity". In: HERDT, Gilbert (Ed.). Third Sex, Third Gender: Beyond Sex Dimorphism in Culture and History. New York: Zone Books, 1994. p. 329-372.

ROSEMBERG, Daniel. "Language in the discourse of the emotions.” In: LUTZ, Catherine; ABU-LUGHOD, Lila (Eds.). Language and the Politics of Emotion. Cambridge: Cambridge University Press, 1990. p. 162-185.

SAPIR, Edward. "The Unconscious Patterning of Behavior in Society". In: MANDELBAUM, David (Ed.). Edward Sapir: Selected Writings in Language, Culture and Personality. Berkeley e Los Angeles: University of California Press, 1985. p. 544-559.

SCHIEFFELIN, Bambi B.; OCHS, Elinor. "Language Socialization". Annual Review of Anthropology, v. 15, p. 163-246, Out. 1986. 
SIDELL, Jack. "Organizing Social and Spatial Locations. Elicitations in Indo-Guyanese Village Talk". Journal of Linguistic Anthropology, v. 7, n. 2, p. 143-165, Dez. 1998.

SILVERSTEIN, Michael. "Language and the Culture of Gender: At the Intersection of Structure, Usage and Ideology". In: MERTZ, Elizabeth; PARMENTIER, Richard (Eds.). Semiotic Mediation: Sociocultural and Psychological Perspectives. New York: Academic Press, 1985. p. 219-259.

"Metapragmatic Discourse and Metapragmatic Function". In: LUCY, John. (Ed.). Reflexive Language. Reported Speech and Metapragmatics. Cambridge: Cambridge University Press, 1993. p. 33-58.

SILVERSTEIN, Michael; URBAN, Greg. 1996. "The natural history of discourse." In: Natural Histories of Discourse. Chicago: University of Chicago Press, 1996. p. 1-17.

SPENCER, Baldwin. The Arunta. London: Macmillan, 1927. v. 1 e 2.

SPENCER, Baldwin; GILLEN Francis James. The Native Tribes of Central Australia. New York: Macmillan, 1899. . Across Australia. London: Macmillan, 1912.

STREHLOW, Theodor G. H. "Aranda Phonetics and Grammar". Oceania Monographs, n. 7, Sidney: The Australian National Research Council, 1944.

. Aranda Traditions. Melbourne: Melbourne University Press, 1947.

STOCKING Jr., George W. After Tylor: British Social Anthropology, 1888-1951. Madison: University of Wisconsin Press, 1995.

TAN, Michael L. "From Baklato Gay: Shifting Gender Identities and Sexual Behaviors in the Philippines". In: PARKER, Richard; GAGNON, John (Eds.). Conceiving Sexuality. Approaches to Sex Research in a Postmodern World. New York: Routledge, 1995. p. 85-96.

TROEMEL-PLOETZ Senta. "Selling the Apolitical". Discourse and Society, v. 2, n. 4, p. 489-492, Out. 1991.

TRUMBACH, Randolph. "London's sapphists: from three sexes to four genders in the making of modern culture." In: HERDT, Gilbert (Ed.). Third Sex, Third Gender: Beyond Sex Dimorphism in Culture and History. New York: Zone Books, 1994. p. 111-136.

VOGLER, Candance. "Sex and Talk". Critical Inquiry, v. 24, n. 2, p. 328-365. 1998.

WHITEHEAD, Harriet. "The Bow and the Burden Strap. A New Look at Institutionalized Homosexuality in Native North America". In: ABELOVE, Henry; BARALE, Michele Aina; HALPERIN, David M. (Eds.). The Lesbian and Gay Studies Reader. New York: Routledge, 1993. p. 498-527.

WHITNEY, Craig R. "La Ministre? Over the Immortals' Dead Bodies". The New York Times, $1^{\circ}$ Jul. 1998, p. A-4. 
Tradução de Joana Plaza Pinto Universidade Federal de Goiás

[Recebido em 5 de outubro de 2014 e aceito para publicação em 8 de maio de 2015]

\section{Intimate Pragmatics Language: Subjectivity and Gender}

Abstract: This paper discusses metapragmatic and psychoanalytic understandings of language, gender and desire. It discusses the challenge each disciplinary approach to language, gender and desire poses to the other. It argues that a robust theory of language and gender necessitates we view subjectivity as an order of phenomenon distinct from semantic and pragmatic orders of linguistic phenomena. The paper suggests two modest proposals as a way of beginning to understand the interrelationship between language and subjectivity. It begins with a very brief overview of contemporary linguistic anthropological approaches to gender and sexuality. It then describes the intimate pragmatics of speaking-subjects by articulating recent work in metapragmatics and gender with a psychoanalytically inspired account to subjectivity and desire. Key-Words: Language; Gender; Metapragmatics; Psychoanalysis; Subjectivity. 